\title{
Klaipėda (Memel) naval fort - museum
}

\author{
R. Adomavičius \\ Navigation History Department, Lithuanian Sea Museum, Lithuania
}

\begin{abstract}
A $19^{\text {th }}$ Century naval fort housing the Lithuanian Sea Museum (LSM) since 1979 represents the only type of sea shore defence architecture of the German/Prussian Empire in the present territory of the Lithuanian Republic. The hexagonal embankment structure with living quarters built on the very tip of the Curonian Spit between 1865 and 1871 formed a front part of the Memel sea port defence line. It represents a type of naval heritage fortification situated on the eastern shore of the Baltic Sea. The initial goal of the paper is to present a historical sketch of the Nehrungs naval fort, the key function of which was to defend a narrow mouth of the Curonian Lagoon and the Baltic Sea entering the port of Klaipeda. Also, the study analyses how the authentic features and structures of the fort tailors the needs of the museum, how the functions of a historical building conform to the needs of the present day public. Preserving authentic features of the fort and keeping it open for the public is one of the main goals of the Lithuanian Sea Museum's activity.

Keywords: naval fort, history, Memel, Klaipeda, Baltic Sea, port, heritage management, maintaining.
\end{abstract}

\section{Introduction}

The port city with the name Klaipeda located on the eastern coast of the Baltic Sea, near the roots of freshwater lagoon (the Curonian lagoon), in a sovereign Republic of Lithuania first appeared in 1923. During 1939-1945 Klaipeda was under the authority of the Third Reich and during 1945-1990 it was a part of the Lithuanian Soviet Socialist Republic in USSR. In the middle of the $13^{\text {th }}$ Century, the castle built by the German Order (branch of the Knights of the Sword) and the city/port which grew until the beginning of the $20^{\text {th }}$ Century was called Memel (in German: River Nemunas). Almost 700 years of the development in the space of German culture and nationhood has left a significant and "hard to 
move" cultural landscape element that as well as being a witness to the past is becoming newly active in the public life of the rapidly expanding port. One of those participants - the fort of Nerija - emerged at the end of the $19^{\text {th }}$ Century in the northern horn of the Curonian Spit. Since 1979 the Maritime Museum has been situated in the fort of coastal artillery while still retaining much of its authentic structure.

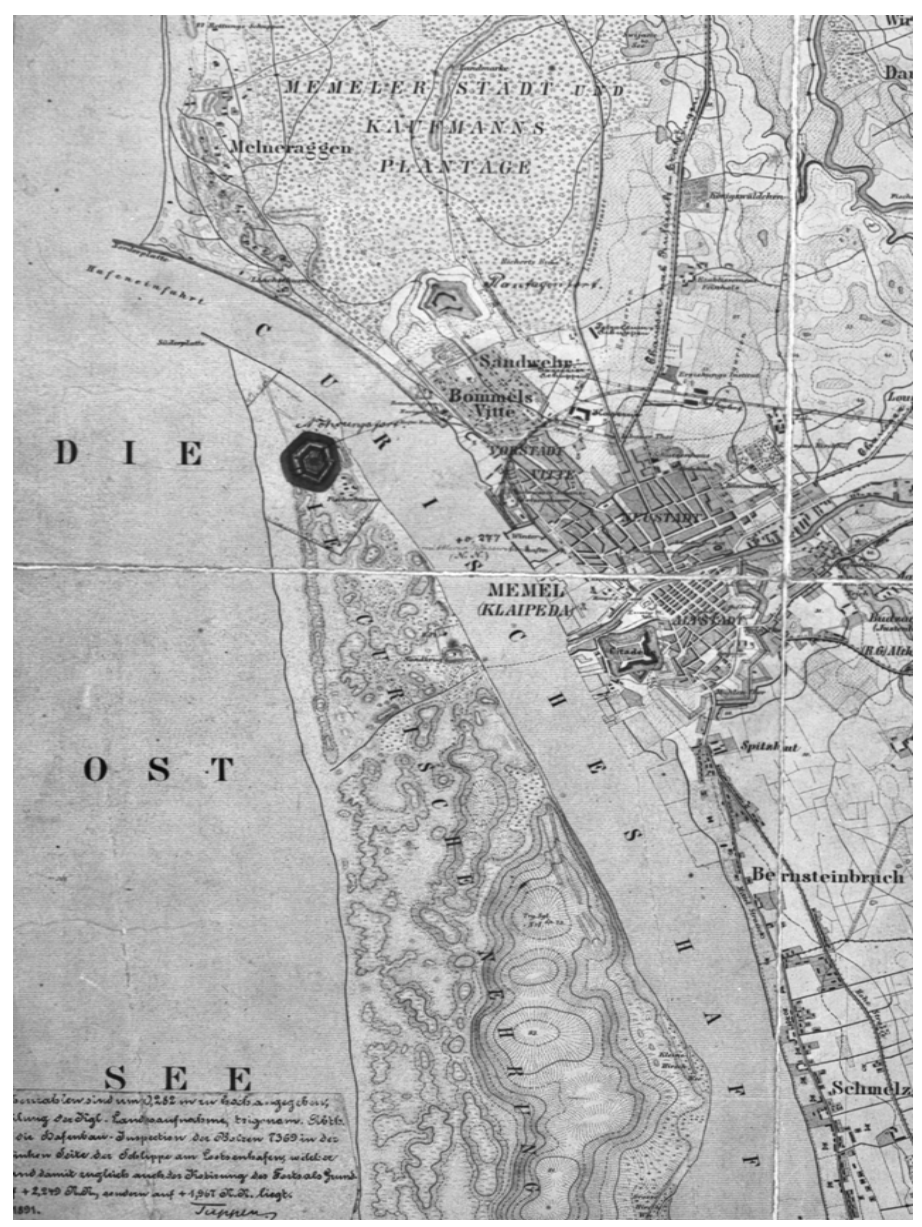

Figure 1: $\quad$ Nerija naval fort depicted in the map of Memel port, 1891.

\subsection{The historical context}

Memel has for centuries been the northernmost port in East Prussia, which can be described as having no economic backing (hinterland). In the $19^{\text {th }}$ Century a dozen miles or so further east stretched the border of the Russian Empire. The main source of income for merchants and the authority of the Royal Prussian Maritime and Commercial City (such was the status of Memel city) since the end 
of the $18^{\text {th }}$ Century was the export of wood-based materials. As closer intercourse with the centre of Prussia was missing, any sudden opportunities for trades during the moments of international upheaval were welcomed. In 1807, $1849,1853-1855,1864$ and 1871-1874 the export of timber to the Western Europe, especially Great Britain, increased significantly and cargo of agricultural crops (wheat, rye, flax, oats, barley, hemp, etc.) were rushed from neighbouring Russia to the ports of war-conscious countries for supplies (Zembrickis [1]). Memel as a minor port remained unblockaded by enemy fleets.

In the second half of the $19^{\text {th }}$ Century in the region of the Baltic Sea nationalist ideas were becoming entrenched. The Kingdom of Prussia (a state from 1701) has played a decisive role in bringing the German lands and cities together into the German Empire. The country was attempting to establish itself as an economic and military power at sea to Kirby (Hinkkanen [2]). The principles of general centralization and unification have contributed to increased costs for border defence Kirby [3]. In the south-eastern coastal strip of the Baltic Sea, controlled by Prussia, with access to East and West Prussia, a system of fortifications were constructed. Various buildings of the seaside fortifications type (redoubts, forts, batteries, bastions, etc.), provided with high-calibre guns, were erected to protect ports from potentially hostile French and British war ships' artillery attacks from the sea. In this section, greatly exceeding $500 \mathrm{~km}$, new coastal fortifications appeared or previously existing ones have been improved. They were located in Swinemünd (now Świnoujście) (Kolberg (Kolobrzeg), Danzig (Gdansk), Piliava (Baltiysk) and Memel (Klaipeda) Bliss [4], Gosch [5]).

The concept of sea forts was inspired by the progress of firearms - it dictated the structural forms of coastal forts of the seventh and eighth decades of the $19^{\text {th }}$ Century. It was thought that a hinge-power gun of the coastal fort replaced three weapons of the same calibre onboard warship because of accuracy and shelter. The fire of forts was thought to reach the targets at a distance of several kilometres. However, the majority of the newly built sea forts remained unused for their original purpose. The evolution of ships' artillery eliminated the forts from the line of reliable defence. In the autumn of 1885 the German navy fired at the experimental ramparts of the fort built $50 \mathrm{~km}$ south of Memel, on the Curonian Spit. The projectiles penetrated to the depth of 6 meters, making huge cracks.

The shots by vessels afloat in the wavy sea were very accurate (Die Alten fort [6]). The testing confirmed the inefficiency of defensive constructions made of moulds of soil covered with bricks. Siege tactics were replaced by a mobile warfare. Since then the coastal forts on the southeast coast of the Baltic Sea have been used for civil needs and purposes. During the world wars of the $20^{\text {th }}$ Century some of them were used as a defence against air attacks.

The defence system of Swinemünd consisting of forts, bunkers, and coastal batteries which guarded both sides of the mouth of the Swine River. The fortifications of the $19^{\text {th }}$ Century were supplemented with heavy coastal artillery against sea and air attacks built in the beginning of $20^{\text {th }}$ Century. After World War II a Soviet naval base was located there. Since the end of the 


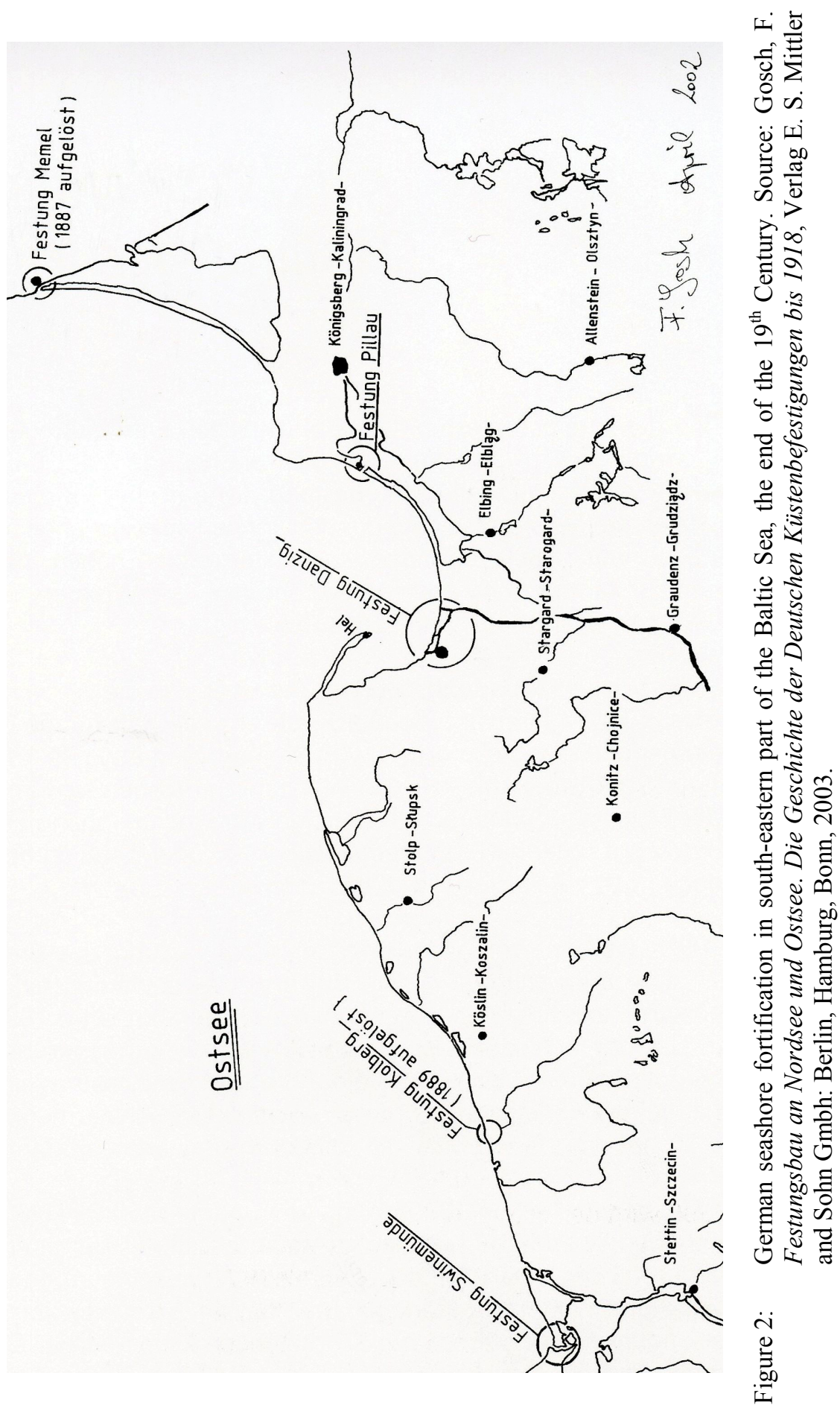


$20^{\text {th }}$ Century some of the unique forts and batteries were opened to visitors. In Kolberg the forts, built at the end of the $18^{\text {th }}$ and the first half of the $19^{\text {th }}$ Century, also lost their military importance in the middle of the $20^{\text {th }}$ Century and were incorporated into the structures of city and port: a restaurant and an amphitheatre were established in the forts. A lighthouse still operating nowadays was built in 1945 in one of the forts (Fort Münde) while in the redoubt, a part of the harbour defence system, a marina has been located. At the mouth of the River Vistula (Wisla), a round fortress with a tower built at the approaches to Danzig since the $14^{\text {th }}$ Century lost its military importance after the World War I. It was destroyed during World War II, but later restored and since 1974 opened as the Danzig Historical Museum Neumann (Dornbusch [7]). The strategically important port of Piliava, situated on the Aistmares channel leading to the Baltic Sea was defended by a fortress and two forts in $19^{\text {th }}$ Century. Now nothing but the remnants are observable.

\section{Naval Fort of Nerija (Nehrungs Fort)}

The emergence of military fortifications in the northern end of the Curonian Spit, in front of Memel, was prompted by the topography, environmental conditions and historical developments in the region. From the first half of the $18^{\text {th }}$ Century planned fortifications were developed to guarantee the defence of Memel channel - the only exit point from the bay into the Baltic Sea. During the Prussia's war with Napoleon Bonaparte (1811-1812) the fairway of Memel port and the city were defended by batteries and redoubts, and fascine buildings (Elertas [8]).

\subsection{The rise of the fort}

The need for better defence of Memel port arose during the German unification wars. In 1865 the technically advanced project of Nerija fort (Nehrungs fort) for gunners and artillery was starting to be implemented. First, a redoubt (also called casemate) - a ring-shaped two-storey dwelling, 40m in diameter with shooting holes (embrasures) and gunpowder basements was built. The roof of casemate was covered with soil and turf. The closed yard, $20 \mathrm{~m}$ in diameter, was equipped with the mechanism of a fresh water well (Elertas [8], Tatoris [9], Mačiulaitienè [10]). Two thirds of the casemate were covered by an earthen mound. Later, a $14 \mathrm{~m}$-high rampart formation in the shape of an irregular hexagon was formed around the redoubt. The Nerija Fort ramparts were covered with soil previously used as ballast for sailing ships. Underneath, the ramparts concealed a vaulted underground chamber, for stores of supplies and ammunition, the garrison toilet - latrine. The point of the fort was formed of two long mounds (like curtains) facing the sea. The two shorter ones turned to Memel and formed the neck, and the remaining two more made the flanks. The fort was not finished until the Prussian-Austrian war (1866), but the construction was completed by 1871 . Local material was used for the construction of masonry: bricks and clinker from the surrounding brickyards of Memel Mačiulaitienè [10]. 


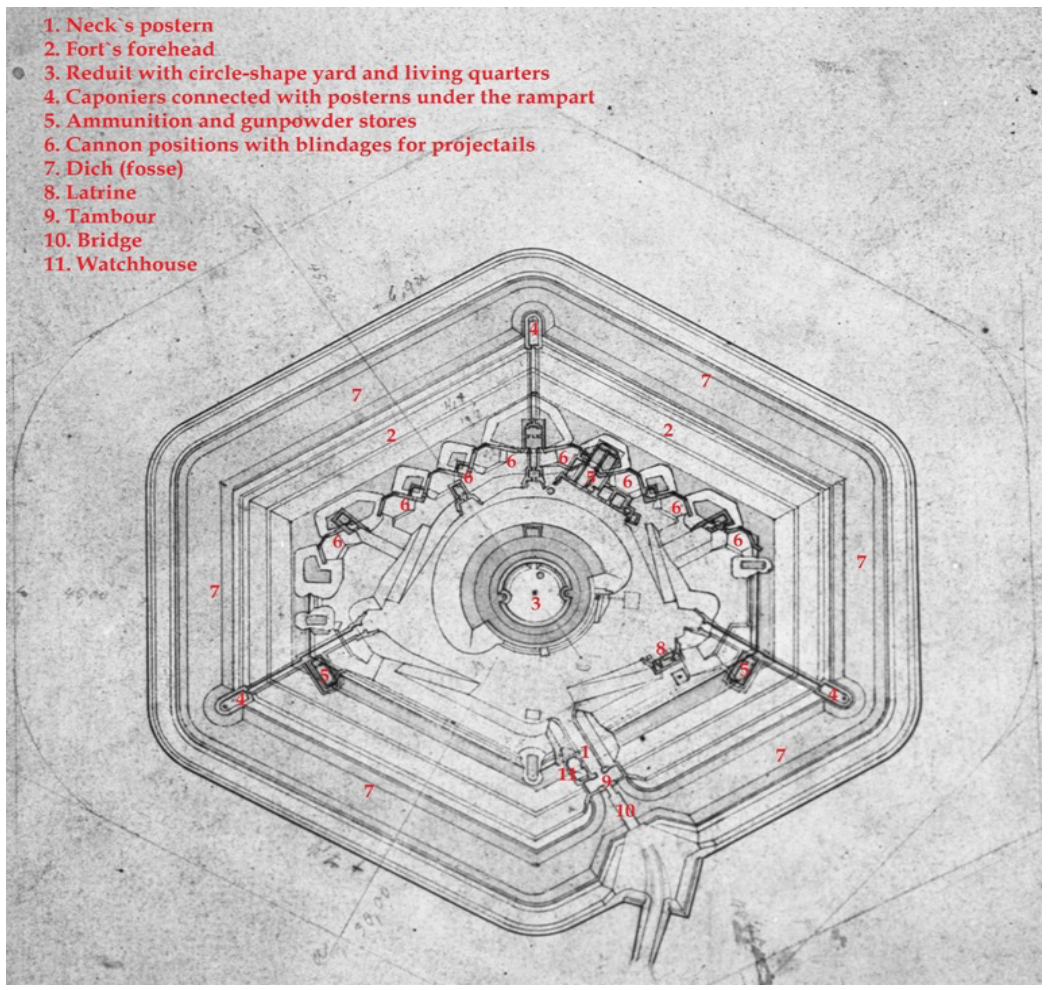

Figure 3: $\quad$ Nerija naval fort (Nehrungs fort) project, 1878.

The plans of construction and inventory, held by the Lithuanian Sea Museum, Každailis (Šliogeris [11]) which came from the state archive of Mersenburg in Germany show the structural design of the fort quite clearly, however it is difficult to decide about the date of exact completion of separate parts of the complex. In 1873, after the establishment of the German Empire, the government issued the order to fortify mouths of the rivers and ports of the Baltic Sea. Following it, the Forest fort (Plantagenfort) situated in front of the Nerija fort across the lagoon was built during 1867-1873 (Zembrickis [1]). In 1877-1887 the Nerija fort was developed, too: additional ammunition depots, yards and platforms for big calibre artillery guns were installed (1877), the parapet, previously designed to protect the shooters, was raised. The fort was adapted for circle defence and was considered as a poligone system.

At the beginning of the last decade of the $19^{\text {th }}$ Century, Nerija fort reached the peak of its development. At the time, the rampart was surrounded by a $45 \mathrm{~m}$-wide glacis and a 2-2-deep water fossa with a width of 12 metres, also known as moat. There were vaulted stores for gunpowder and weapons established under the rampart from the western to the north-eastern side. In the blindages, equipped with 8 heavy artillery positions, sufficient ammunition for one day of a battle was stored. There was a lift installed in one of the blindages to provide the 
ammunition directly from the storage onto the rampart. The entrance to the fort was defended by 3 shooters' caponiers protruding into the water in the moat. The thickness of their walls reached $1,5 \mathrm{~m}$ and each of them had 17 shooting holes (embrasures), aiming at all the directions. The caponiers and the inner yard were connected by three covered corridors: posterns. Storage rooms were installed in the side parts of the central posterns in the north-east and southwest. The western postern was shorter. The fort had the only entrance - a mobile metal bridge situated in the East. The tambour joining the bridge and the entrance was guarded by four embrasures. The neck postern leading to the yard of the fort was hollowed out under the rampart. There were two gates (wooden and metal) mounted and in front of them the watchhouse was built. The slopes of the fort were afforested with prickly Hawthorn (Crataegus macracantha) (Elertas [8], Mačiulaitienè [10]).

\subsection{The loss of military importance and change of purpose}

As the naval artillery tests in Curonian Spit in 1885 proved, the forts of Memel lost their strategic importance, because they were not effective in resisting attacks from the sea. The forest fort (Plantagenfort) was blown up in 1888 and in the first half of the $20^{\text {th }}$ Century the current sports stadium appeared in its place. Some remnants of the rampart of the fort still exist under the stadium stands (Tatoris [9]). As in the case of Forest fort, Nerija fort remained unused for its direct defensive purpose. Ever since 1879, (until 1900), there was a rural school opened in the redoubt of the fort Kopgalis, where A. Hannemann, a Warrant Officer of the warehouse taught. In 1897 the infantry garrison of the fort was moved, guns dismounted, and the former military complex finally passed into the civilian hands (Elertas [8], Švambrys [12]).

Eventually the civilians settled in the fort and it was employed for the needs of the expanding port. In 1902 the meteorological semaphore was built on the northern rampart of the fort. The semaphore reported weather conditions at the approaches to Klaipeda port to arriving and departing vessels. The families of the port officials were living in former barracks. Abandoned storage spaces of the fort were used by the port authority and the supervisor of the dunes as a warehouse. During World War I, when Memel was attacked by the Russian troops in the early spring of 1915 , the local population moved to the Curonian Spit, where some people found a refuge in the fort for a few days (Zembrickis [13]). After 1923, when Klaipeda (Memel) became a city of the young independent Republic of Lithuania, the fort served as a summer camp for Maritime School students, who spent the summers of 1924 and 1925 there. 15 families of port officials and seafarers, also the sea scouts and border police were dwelling in the premises of the fort. In the fourth decade of the $20^{\text {th }}$ Century the moat of the fort was connected to the lagoon and the entrance was fortified with jetties. The boats of border guards, port authority, port police, and fishermen were moored in the moat. Also there was a boat-rental service for citizens provided. There was a direct connection between Nerija fort and Klaipeda by motorboats (Elertas [8], Každailis [14], Baranauskas [15]). Klaipeda citizens and the holidaymakers used to visit the fort to experience the mystical spirit of the 
former fortress. So, at the beginning of the $20^{\text {th }}$ Century Nehrungs fort was widely open for the needs of the local community. It is also worth noticing that from the very beginning of the establishment the fort has not entirely been closed for the public. The fort and its personnel were employed for educational needs when Kopgalis village school was operating there from 1880s. This case illustrates how highly education was treated in German empire at the end of $19^{\text {th }}$ Century. The fact also proves that the fort was used for civil needs since its early beginnings.

During World War II the fort fell under the soldiers' rule. In 1939 Germany recovered the region of Klaipeda, and the ammunition storehouses were established in the Nerija fort. In the former positions of coastal artillery the antiaircraft guns were established. Retreating German troops blew up the central fort casemate (redoubt) and the bridge over the moat before the USSR Red Army came in 1945. Until 1975 the fort remained in a closed border zone, and was inaccessible for the majority of the citizens (Elertas [8], Baranauskas [16]). The fort stayed derelict and partly ruined, just some caponiers were used as storage.

\section{Fort - maritime museum and aquarium}

In the past the northern part of the Curonian Spit was underpopulated. Kopgalis village (in German Süderspitze) was founded at the beginning of the $19^{\text {th }}$ Century to settle the people who worked in the field of aforestation of the sand dunes and did mounting works of sandy shores forming the cape. At the beginning of the $20^{\text {th }}$ Century there were 20 buildings and 134 residents in Kopgalis village. After World War II it became extinct (Baranauskas [17]). Following to the south from Kopgalis village the villas of wealthy citizens' were erected. The rise of Nerija fort did not interfere with the urban area and its landscape as Kopgalis together with Nerija fort were separated from the mainland by lagoon. Young conifer forest and sparse shrubs dominated in the landscape.

After World War II the narrow strip of the Curonian Spit and its white sandy beaches became an attraction for the residents of Klaipeda and holidaymakers from all over the former Soviet Union, thereat it was in 10 minutes-reach going from the centre of the city by ferry. An imposing complex of Nerija fort stayed derelict for 30 years. Relating it to the political situation, it was ideologically wrong for the Government of the former Soviet Union to take care of the former German fort. Nevertheless, a decision was made to start the restoration of the fort in 1969. The plan of works covered restoration of destroyed central casemate (redoubt), ramparts, and cleaning of the defensive ditch (moat). The project was initiated by contemporary head of Klaipeda municipality Alfonsas Žalys, who conceptualized the development of Klaipeda as a cultural centre, Nerija fort seeing as one of cultural and tourism attractions. Connection of German heritage and so called national communism local policy of Lithuania Soviet Republic embodied the ideas establishing sea museum and aquarium. Restoration of the former German fort was kept secret from the ears and eyes of Moscow for almost 10 years (Každailis [18]). Planning and designing of the restoration was performed by the specialists of preservation of monuments of LSSR Institute of 


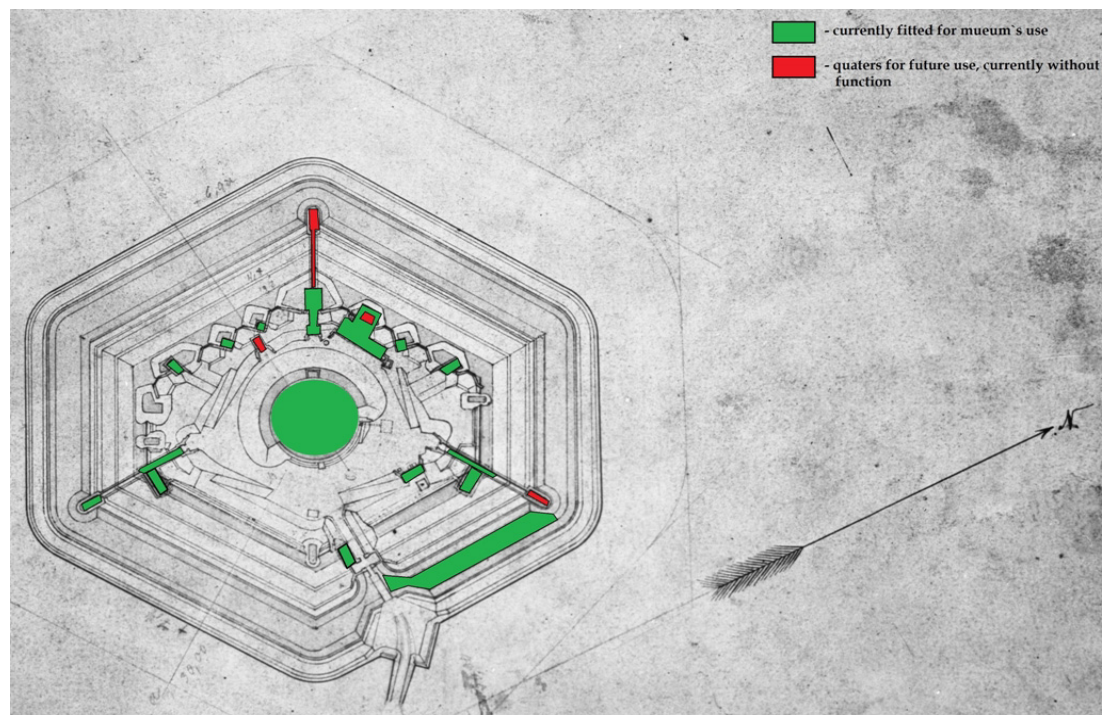

Figure 4: Facilities of the fort adapted for the maritime museum and aquarium use (green colour) and intended to employ in the future (red colour), situation in 2012. (See online for colour version.)

Klaipeda department. Real works started in summer 1973, after soldiers cleaned the fort from war missiles and builders and restorers took their work (Každailis [14]). Nerija fort was restored by the efforts of the museum curators and Klaipeda municipal government. Restoration of the architectural and engineering object developed in the $19^{\text {th }}$ Century was a great interest and challenge for the specialists. The government of contemporary Klaipeda, guided by the national communism manifestations in the period of USSR stagnation, took its responsibility and demonstrated a kind of independence establishing the cultural attraction near the town. Approved by the municipal government, the port and other industrial companies of the city supported the development of the museum.

Previously associated with mythical ghost stories and secret underground tunnels, the fort became open and a widely visited place of attraction. The authentic features of the design were maintained in fort ramparts and defensive zones. One (of three) caponier, two (of three) posterns and the most of the ammunition storage facilities situated under ramparts were adapted to the needs of the Navigation history exhibitions. The exhibitions present local maritime tradition in the context of the world history. The anchors collected from the Baltic Sea seabed are displayed at former artillery gun sites on the rampart (Každailis [19]). The central circular building (former casemate) houses the aquarium and instead of the inner yard, having covered it with the roof, the central pool has been arranged. The marine fauna exhibition and dozens of aquariums are displayed on two floors of the central building. The rampart initially covering the casemate (redoubt) was removed and instead five outdoor swimming pools for penguins, seals and sea lions were arranged. The arena for 
outdoor staging and some of technical facilities have been attached to the outside walls of the round building. The ramparts of the fort are sorted and collated. The moat, detached from the access to the lagoon, has been cleaned up, deepened, and populated with fish and seals. The guard's house, situated at the entrance, houses a souvenir shop. The Lithuanian Sea Museum, established among the stonework walls of the fort is one of the most popular museums in Lithuania, attracting up to 300000 visitors per year (www.muziejus.lt [20]).

Nevertheless, to maintain such a complex and heritage object is rather a challenge. Mentioning some of them are: limited space for exhibition displays, limits to engineering and design development, high concentration of humidity in the rooms under rampart after heavy rains or snow melting, technically complicated cleaning of ventilation system.

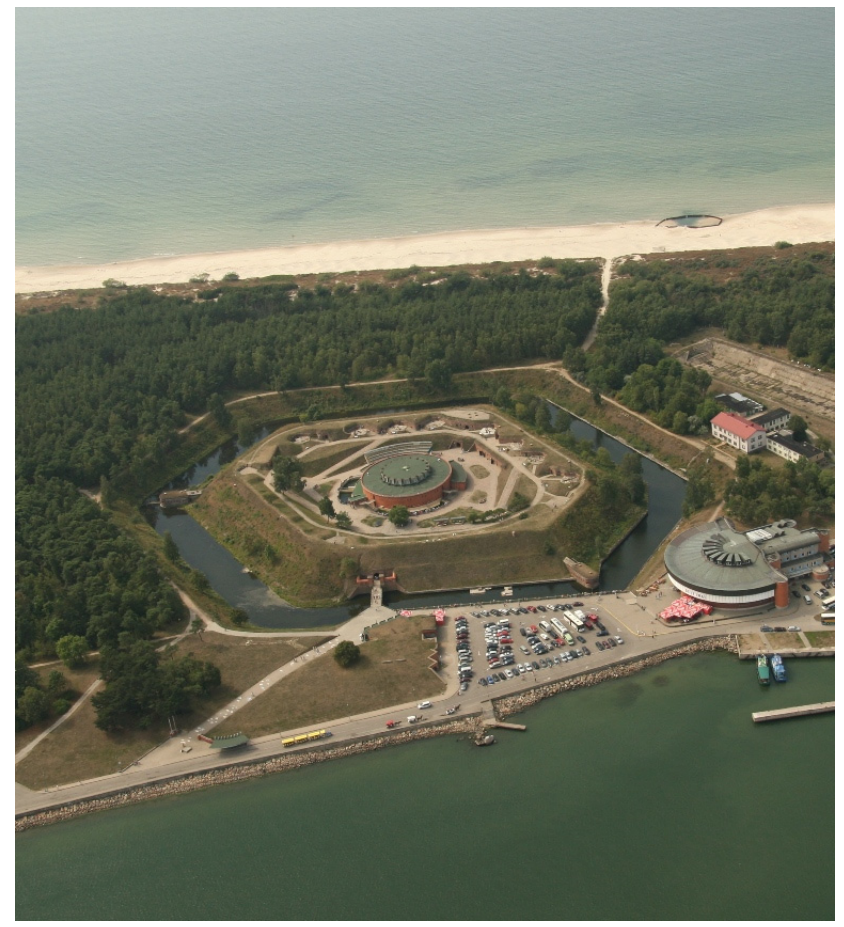

Figure 5: $\quad$ Lithuanian Sea Museum, 2006. Photo A. Mažūnas.

\section{Conclusions}

From the end of the $19^{\text {th }}$ Century Nerija fort (Nehrungs fort) has been constantly transformed in relation to its changing function. Generally being a military site, the fort has also served for social duties: education, housing, and starting from 1969 - continuous socialisation in different forms. 
The revival of a single coastal fortification construction of German (Prussian) tradition on the sea shore of Lithuania is a consequence of favourable circumstances. During the occupation period of USSR, the fort was a subjected to the public property, so it was easy to consolidate all the efforts and resources to restore the fort. Conservation and restoration works are based on active economic and cultural activity, natural environment and ecological grounds. Situated in a rather distance from the city the fort preserved its natural environment and escaped the impact of townscape. It was easy to preserve authentic structures of the fort as it stood almost untouched for the last 140 years (except war damage) and had limited access. The museum, founded in this location, on its turn boosts the fort's economic liveliness. Nevertheless, the main task is to apply naval fort's military space for museum use and maintain its cultural and tourism attraction as a single object.

Similarly as the analogous destinations situated along the south-eastern coast of the Baltic Sea (Swinoujscie, Kolobrzeg, Gdansk and Baltiysk) Nerija fort (Nehrungs fort) is a culture heritage object successfully applied to the countries needs developing tourism and economic attractiveness. The museum opened in the fort and constant flow of the visitors keeps the fort alive. Successfully applied model of cultural management (the dolphinarium was built nearby) provides with more possibilities to develop and update the exhibitions in the authentic premises.

\section{References}

[1] Zembrickis, J., Klaipèda XIX amžiuje, II t., Libra Memelensis: Klaipėda, p.27-34, 2004.

[2] Kirby, D., Hinkkanen M.L., The Baltic and the North Seas, Routledge: London and New York, pp.128-130, 2000.

[3] Kirby, D., The Baltic World 1772 - 1993, Europe 's Northern Periphery in an Age of Change, Longman: London and New York, pp.169-172, 1995.

[4] Bliss, W., Die Festungspläne des preussischen Kriegsministeriums. Ein Inventar. Böhlau Verlag: Köln, S. 753-782, 2008.

[5] Gosch, F. Festungsbau an Nordsee und Ostsee. Die Geschichte der Deutschen Küstenbefestigungen bis 1918, Verlag E.S.Mittler and Sohn Gmbh: Berlin, Hamburg, Bonn, S. 27-33, 2003.

[6] Die Alten Forts. Memeler Dampfboot, November 11, S. 169-170, 1985.

[7] Neumann, H.R. \& Dornbusch, R.S., (eds). Baltic Cultural and Tourism Route Fortresses. Appropriate Monumental Use of Fortresses (Documentation and recommended proceeding, European University Viadrina Frankfurt (Oder): Frankfurt (Oder) and Berlin, pp.34-44, 2007.

[8] Elertas, D. Kopgalis, Libra Memelensis: Klaipèda, p.30-45, 2002.

[9] Tatoris, J. Senoji Klaipèda: urbanistinè raida ir architektūra iki 1939 m., Mokslo ir enciklopedijų leidykla: Vilnius, p.164-166, 1994. 
[10] Mačiulaitienè, I. Klaipėdos jūrų muziejus ir akvariumas Kopgalio tvirtovejje (Graduation dissertation in Vilnius University), Typescript: Klaipèda, p.410, 1985.

[11] Každailis, A. \& Šliogeris, V. Kopgalio tvirtovè. Mokslas ir gyvenimas, 8, p.50-51, 1973.

[12] Švambrys, H. Kopgalis. Mokslas ir gyvenimas, 7, p.18, 1979.

[13] Zembrickis, J. Klaipédos apskrities istorija, III t., Libra Memelensis: Klaipėda, p.329-347, 2011.

[14] Každailis, A. Kopgalio tvirtovè. Lietuvos žvejys, 30 (263), p.9, 1980.

[15] Baranauskas, M. 3.Dingusios įdomybès. Lietuvos žvejys, 20 (253), p.9, 1980.

[16] Baranauskas, M. 4.Antroji jaunystè. Lietuvos žvejys, 21 (254), p. 9, 1980.

[17] Baranauskas, M. 2.Buvęs Kopgalio kaimas. Lietuvos žvejys, 17 (250), p.9, 1980.

[18] Každailis, A. Smagios sunkios dienos, Lietuvos jūrų muziejus: Klaipèda, p.140 - 160, 2009.

[19] Každailis, A. Kviečia jūru muziejus. Mintis: Vilnius, p.32-43, 1981.

[20] Lithuanian Sea Museum, www.muziejus.lt 